\title{
The Classical Review
}

http://journals.cambridge.org/CAR

Additional services for The Classical Review:

Email alerts: $\underline{\text { Click here }}$

ma mas

Subscriptions: Click here

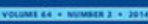

Commercial reprints: Click here

Terms of use : $\underline{\text { Click here }}$

\section{Version}

R. C. Seaton

The Classical Review / Volume 21 / Issue 01 / February 1907, pp 29 - 29

DOI: 10.1017/S0009840X00181971, Published online: 27 October 2009

Link to this article: http://journals.cambridge.org/abstract S0009840X00181971

How to cite this article:

R. C. Seaton (1907). Version. The Classical Review, 21, pp 29-29 doi:10.1017/ S0009840X00181971

Request Permissions : $\underline{\text { Click here }}$ 
The Greek War of Independence, being a Greek Text for Beginners. By Charles D. Chambers. London: Swan Sonnenschein and Co., 1906. Pp. $x+204.35$.

An excellent idea, well carried out, in spite of some doubtful points of scholarship. The plan adopted is that of Prof. Sonnenschein's Ora Maritima: a historical story (and one of importance) is retold in simple Greek, the chapters being progressive in difficulty. The vocabulary and phrasing are modelled on Thucydides. Grammar and vocabulary are added.

The Philoctetes of Sophocles. Abridged from the larger edition of Sir RICHARD JEBB by E. S. Shuck burgh, Litt.D. Cambridge: University Press, rgo6. Pp. xliii +228 . $4 s$.
We suppose this abridgment is intended to reduce the price of the original for the benefit of schoolboys. Certainly any pupil who is advanced enough to profit by this book had much better study the original. It is not at all suited for school work : it contains too much in one direction and too little in another.

$A$ History of Classical Scholarship from the Sixth Century B.C. to the End of the Middle Ages. By John Edwin Sandys, Litt.D. Cambridge : University Press, I906. Pp. xxiv + 702. Ios. $6 d$. net.

That a second edition of Dr. Sandys' learned work should be called for so soon proves that he has supplied a real want. All scholars will look forward to the publication of the concluding volume.

\section{VERSION}

LIFE is mostly froth and bubble,

Two things stand like stone,

Kindness in another's trouble,

Courage in your own.

AdAM Lindsay GoRdon.

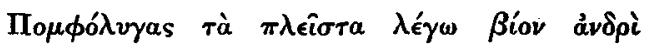 $\tau \in \tau \dot{x} \theta a \iota$,

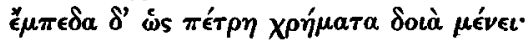

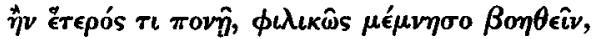

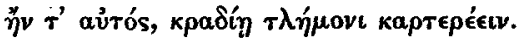

R. C. Seaton

\section{ARCHAEOLOGY}

\section{MONTHLY RECORD.}

GREECE.

Argos.-The principal results of excavations between June and September last year were as follows. Some hundred yards N. of the ancient theatre is a polygonal wall, above which are the remains of a Roman structure in brick. The terrace supported by the wall has been completely cleared, with the result that the foundations of a small temple in tufa have been discovered. The Roman building proves to have contained reservoirs in connection with an aqueduct. The headless statue of the builder of this aqueduct has been discovered. S. of the modern town the foundations of a prostyle temple in calcareous stone have been brought to light. Here were found several inscribed stelai, including a fragment of a fifth century в.c. treaty made at Argos between the Cretan towns of Knossos and Kylissos, and a decree of the third century B.c. in honour of the Rhodians, who had lent 100 talents to the Argives to enable them to repair the walls of the town and to reorganize their cavalry. ${ }^{1}$

\section{AFRICA.}

Bulla Regia.-The most interesting object recently discovered is a circular collar in the form of a narrow band of lead. This is inscribed on the exterior as follows :

ADVLTERA MERETRIX TENE QVIA FVGIVI DE BVLLA R(e)G(ia). ${ }^{2}$

1 Acad. des Inscr. Oct. 1906.

2 Ibid. Aug. I906. 